\title{
3-Epiabruslactone A, a New Triterpene Lactone Isolated from
}

\section{Austroplenckia populnea}

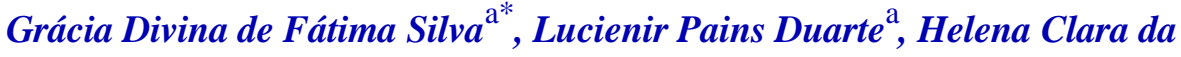 \\ Silva Paes ${ }^{\mathrm{a}}$, José Rêgo de Sousa ${ }^{\mathrm{a}}$, Maria Cristina Nonato ${ }^{\mathrm{b}}$, Paulo José \\ Portezani $^{\mathrm{b}}$ and Yvonne Primerano Mascarenhas ${ }^{\mathrm{b}}$ \\ ${ }^{a}$ Departamento de Química, ICEx, Univ. Fed. de Minas Gerais, C.P. 702, \\ 30123-970 Belo Horizonte - MG, Brazil \\ ${ }^{\mathrm{b}}$ Departamento de Física e Informática, IFSC, USP, 13560-280, S. Carlos - SP, Brazil
}

Received: May 17, 1997

\begin{abstract}
Um triterpeno lactônico inédito isolado do cerne de Austroplenckia populnea (Celastraceae) foi caracterizado como $3 \alpha$-hidroxiolean-12-en-29,22 $\alpha$-olídeo (a $\gamma$-lactona do ácido $3 \alpha, 22 \alpha$-diidroxiolean-12-en-29 $\alpha$-óico), o epímero em C-3 da abruslactona A, com base em dados espectrais, oxidação e análise cristalográfica.

A new lactonic triterpene isolated from the heartwood of Austroplenckia populnea (Celastraceae) was characterized as $3 \alpha$-hydroxyolean-12-en-29,22 $\alpha$-olide (the $\gamma$-lactone of the $3 \alpha, 22 \alpha$ dihydroxyolean-12-en-29 $\alpha$-oic acid), the 3 -epimer of the abruslactone A, on the basis of its spectral data, chemical transformations, and single crystal X-ray analysis.
\end{abstract}

Keywords: Austroplenckia populnea, Celastraceae, 3-epiabruslactone A, structure elucidation

\section{Introduction}

The investigation of chemical constituents of plants of the Celastraceae family has aroused considerable attention on account of the antitumoral and anti-leukemic activities found in maytansinoids and quinonemethide triterpenes isolated from plants of that family ${ }^{1}$.

In previous papers we described the chemical constitution of the root bark ${ }^{2}$, bark wood ${ }^{3}$ and root wood $^{4}$ of Austroplenckia populnea (Reiss) Lundell, specimen of the Celastraceae family. The plant is popularly known in the state of Minas Gerais as "mangabeira-brava", and it is a source of material for the industry of vimen furniture. The decoction of its branches is used as a traditional antidysenteric medicine 5 .

During our continued investigation of this species, one new oleanane derivative (1) has been isolated along with an extensive range of triterpenes including the known lactonic triterpene abruslactone A (2). The compound $\mathbf{1}$ showed spectral characteristics of an abruslactone A de- rivative. Thus, in this paper we present the identification of abruslactone $\mathrm{A}$ and structural elucidation of a new triterpene lactone, the epimer in C-3 (1) of abruslactone A, whose chemical structures are shown in Fig. 1. Both triterpenes were isolated from the ethanolic extract of the heartwood of Austroplenckia populnea, from which were also isolated the following triterpenes previously found in other parts of the same plant: 3-oxofriedelan-29 $\alpha$-oic acid (populnonic acid) ${ }^{1,2,3}$, 3-hydroxy-2-oxofriedelan-3-en-29 $\alpha$ oic acid, $3 \beta$-hydroxyolean-12-en-29 $\alpha$-oic acid (epikatonic acid) $^{2}$, and 3-oxoolean-12-en-29 $\alpha$-oic acid (katononic acid $)^{2}$.

\section{Experimental}

\section{General experimental procedure}

IR, NMR, mass spectroscopy, and melting point. IR spectra were obtained with a Galaxy FTIR 3000-Mattson in $\mathrm{KBr}$ pellets. A Bruker AC-200 $\left({ }^{1} \mathrm{H}: 200 \mathrm{MHz} ;{ }^{13} \mathrm{C}: 50,3\right.$ 


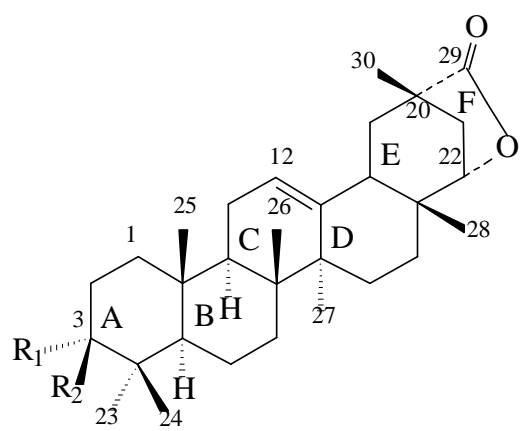

$1 \mathrm{R}_{1}=\mathrm{OH}, \mathrm{R}_{2}=\mathrm{H}$

$2 \mathrm{R}_{1}=\mathrm{H}, \quad \mathrm{R}_{2}=\mathrm{OH}$

Figure 1. Chemical Structure for $\mathrm{C}_{30} \mathrm{H}_{46} \mathrm{O}_{3}$.

$\mathrm{MHz}$ ) was used for the measurement of the ${ }^{13} \mathrm{C}-\mathrm{NMR}$ and ${ }^{1} \mathrm{H}-\mathrm{NMR}$, using $\mathrm{CDCl}_{3}$ as solvent and TMS as internal standard. The multiplicities of the ${ }^{13} \mathrm{C}$ signals were determined by means of the DEPT method. Mass spectra were obtained using an HP mass spectrometer. Melting points were determined using a Leitz thermic microscope without corrections.

\section{3-Epiabruslactone A (1)}

Mp. $295-296^{\circ} \mathrm{C}\left(\mathrm{CHCl}_{3} / \mathrm{MeOH}\right),[\alpha]^{20}+40.1^{\circ}(\mathrm{c}=1.0$, $\mathrm{CHCl}_{3}$ ), MS: $\mathrm{m} / \mathrm{z} 454[\mathrm{M}]^{+}, 246$ (100) and 207 [RDA C ring $]^{+}$, IR max: 3550 and $1755 \mathrm{~cm}^{-1},{ }^{1} \mathrm{H} \mathrm{NMR}\left(\mathrm{CDCl}_{3}, 200\right.$ $\mathrm{MHz}): \delta(\mathrm{m}) 5.30(\mathrm{t}, 1 \mathrm{H}, \mathrm{J}=4.4 \mathrm{~Hz}), 4.14(\mathrm{~d}, 1 \mathrm{H}, \mathrm{J}=5.6$ $\mathrm{Hz}), 3.40(\mathrm{t}, 1 \mathrm{H}, \mathrm{J}=2.9 \mathrm{~Hz}), 1.20,1.09,0.95,0.95,0.92$, 0.86, 0.84 (s, 3H each), ${ }^{13} \mathrm{C}-\mathrm{NMR}$ : Table 1.

\section{Abruslactone A (2)}

Mp. 319.5-322.0 ${ }^{\circ} \mathrm{C}\left(\mathrm{CHCl}_{3} / \mathrm{MeOH}\right),[\alpha]^{20}-34.2^{\circ}(\mathrm{c}=$ $\left.1.0, \mathrm{CHCl}_{3}\right),{ }^{1} \mathrm{H} \mathrm{NMR}\left(\mathrm{CDCl}_{3}, 200 \mathrm{MHz}\right): \delta(\mathrm{m}) 5.30(\mathrm{t}$, $1 \mathrm{H}, \mathrm{J}=3.0 \mathrm{~Hz}), 4.17(\mathrm{~d}, 1 \mathrm{H}, \mathrm{J}=5.0 \mathrm{~Hz}), 3.2(1 \mathrm{H}, \mathrm{dd}, \mathrm{J}=$ 6.0, $9.0 \mathrm{~Hz}$ ), 1.21, 1.07, 0.99, 0.94, 0.93, 0.87, 0.79 (s, 3H each) in good agreement with previously reported data by Budzikiewicz, Wilson and Djerassi ${ }^{10}$, Chang, Chiang and $\mathrm{Mak}^{11}$ and Nozaki et at. ${ }^{12}$

\section{3-oxoolean-12-en-29,22-olide (Oxidation of 1 or 2 )}

$10.0 \mathrm{mg}$ of $\mathbf{1}$ (or 2) and $200.0 \mathrm{mg}$ of $\mathrm{BaMnO}_{4}$ in 10.0 $\mathrm{mL}$ of $\mathrm{CH}_{2} \mathrm{Cl}_{2}$ were refluxed for $120 \mathrm{~h}$. Filtration and evaporation of the solvent furnished a residue that was submitted to $\mathrm{SiO}_{2}$ gel column chromatography. The product of the reaction was obtained in $40 \%$ yield by elution with $\mathrm{CHCl}_{3} / \mathrm{MeOH}$ (19:1). Mp. 289-290 ${ }^{\circ} \mathrm{C}$, IR max: 1770 and $1700 \mathrm{~cm}^{-1}$.
Table 1. ${ }^{13} \mathrm{C}-\mathrm{NMR}$ data of compound 1 in $\mathrm{CDCl}_{3}$ ( $\delta$ in ppm).

\begin{tabular}{lrcr}
\hline Carbon & $\delta(\mathrm{m})$ & Carbon & $\delta(\mathrm{m})$ \\
\hline 1 & $33.8(\mathrm{t})$ & 16 & $24.2(\mathrm{t})$ \\
2 & $25.2(\mathrm{t})$ & 17 & $35.2(\mathrm{~s})$ \\
3 & $76.0(\mathrm{~d})$ & 18 & $43.4(\mathrm{~d})$ \\
4 & $37.3(\mathrm{~s})$ & 19 & $39.8(\mathrm{t})$ \\
5 & $48.9(\mathrm{~d})$ & 20 & $42.6(\mathrm{~s})$ \\
6 & $18.2(\mathrm{t})$ & 21 & $33.1(\mathrm{t})$ \\
7 & $33.0(\mathrm{t})$ & 22 & $83.1(\mathrm{~d})$ \\
8 & $39.4(\mathrm{~s})$ & 23 & $28.2(\mathrm{q})$ \\
9 & $47.3(\mathrm{~d})$ & 24 & $16.9(\mathrm{q})$ \\
10 & $37.1(\mathrm{~s})$ & 25 & $15.4(\mathrm{q})$ \\
11 & $23.4(\mathrm{t})$ & 26 & $21.0(\mathrm{q})$ \\
12 & $124.6(\mathrm{~d})$ & 27 & $24.9(\mathrm{q})$ \\
13 & $140.2(\mathrm{~s})$ & 28 & $24.2(\mathrm{q})$ \\
14 & $39.5(\mathrm{~s})$ & 29 & $182.4(\mathrm{~s})$ \\
15 & $25.2(\mathrm{t})$ & 30 & $22.3(\mathrm{q})$ \\
\hline
\end{tabular}

\section{$X$-ray crystallography}

Data collection and processing. The X-ray diffraction data were obtained at $c a .293 \mathrm{~K}$ on a CAD-4 Enraf Nonius diffractometer using Mo K $\alpha$ radiation monochromated by graphite. Intensity data for both crystals were collected in the $2 \theta$ range from 1 to $21^{\circ}$, using $\omega-2 \theta$ scans with the scan width given by $(0.8+0.35 \operatorname{tn} \theta)$ and corrected for the Lp factors using the Enraf Nonius Structure Determination Package ${ }^{6}, h k l$ range: $0<h<11,0<k<14$, and $-2<l<16$. Single crystal size $0.53 \times 0.45 \times 0.35 \mathrm{~mm}$. Total number of reflections measured: 1849 of which 1798 independent and 1677 had I $>2 \sigma$, and two standard reflections were monitored every hour which however did not present any significant changes in intensities.

\section{Results and Discussion}

Compounds 1 and 2 analyzed as $\mathrm{C}_{30} \mathrm{H}_{46} \mathrm{O}_{3}\left([\mathrm{M}]^{+}, \mathrm{m} / \mathrm{z}\right.$ 454), and presented a positive Liebermann-Burchard test for a pentacyclic triterpene. The presence of hydroxyl and lactonic carbonyl groups for $\mathbf{1}$ or $\mathbf{2}$ was shown by the bands at 3550 and $1755 \mathrm{~cm}^{-1}$ in the IR spectra. The ${ }^{1} \mathrm{H}-\mathrm{NMR}$ spectrum of 1 presented singlet signals corresponding to the seven tertiary methyl groups $(\delta 1.20,1.09,0.95,0.95$, $0.92,0.86$ and 0.84 ), a signal attributed to a vinylic proton at $\delta 5.30(1 \mathrm{H}, \mathrm{t}, \mathrm{J} 4.4 \mathrm{~Hz}, \mathrm{H}-12)$ and two signals assigned to protons of carbinol type: $\delta 4.14(1 \mathrm{H}, \mathrm{d}, \mathrm{J} 5.6 \mathrm{~Hz}, \mathrm{H}-22)$ and $\delta 3.4(1 \mathrm{H}, \mathrm{t}, \mathrm{J} 2.9 \mathrm{~Hz}, \mathrm{H}-3)$. The spectral analysis IR, ${ }^{1} \mathrm{H}-\mathrm{NMR}$ and ${ }^{13} \mathrm{C}-\mathrm{NMR}$, which revealed the presence of thirty signals, including $\delta 182.4$ (C-29); 140.2 (C-13); 
124.6 (C-12); 76.0 (C-3) and 83.1 (C-22), was used to establish that compound 1 contains the backbone of $\beta$-amirine. Both compounds exhibited similar NMR spectra, but the doublet of doublets observed at $\delta 3.22$ (J 6.0 and 10.5 $\mathrm{Hz}$ ) for $\mathrm{H}-3$ in 2 was replaced by a triplet at $\delta 3.4(\mathrm{~J} 2.9 \mathrm{~Hz})$ for $\mathrm{H}-3$ in 1, indicating an axial position for the hydroxyl group at C-3 for 1. Both triterpenes on oxidation with barium manganate in dichloromethane ${ }^{13}$, gave 3-oxoolean12-en-29,22 $\alpha$-olide, confirming that they are epimeric at C-3.

However, compounds $\mathbf{1}$ and $\mathbf{2}$ differ significantly in their melting points and optical rotations [295-296 ${ }^{\circ} \mathrm{C}$, $\mathrm{CHCl}_{3} / \mathrm{MeOH} ;[\alpha]^{20}+40.1^{\circ}$ (c. $1.0 \mathrm{CHCl}_{3}$ )] and [329$330{ }^{\circ} \mathrm{C}$; $317-318^{\circ} \mathrm{C}$; $[\alpha]^{20}-33.4^{\circ}\left(\right.$ c. $\left.\left.0.2 \mathrm{CHCl}_{3}\right)\right]^{10,11}$.

The MS spectrum of compound 1 presented a retroDiels Alder standard fragmentation ${ }^{10}[\mathrm{~m} / \mathrm{z} 246$ (base peak) and 207], indicating that the lactonic ring was localized at rings $\mathrm{D}$ and/or E.

The above data strongly suggested that $\mathbf{2}$ could be identical with abruslactone A isolated by Chang et al. ${ }^{11}$ from Abrusprecatorius (Leguminosae).

As a further confirmation of the structure and stereochemistry of $\mathbf{1}$ and $\mathbf{2}$, an X-ray analysis was carried out for both. As the structure abruslactone was fully confirmed, the $\mathrm{X}$-ray crystal data will be given only for 3-Epiabruslactone. Crystal data. $\mathrm{C}_{30} \mathrm{H}_{46} \mathrm{O}_{3} . \mathrm{M}=454.7 \mathrm{u}$., orthorhombic system, space group P $2{ }_{1}{ }_{1}{ }_{2}, \mathrm{Z}=4, \mathrm{D}_{\mathrm{x}}=1.202 \mathrm{~g} \mathrm{~cm}^{-3} \mu=0.7$ $\mathrm{cm}^{-1}, \mathrm{~F}(000)=1,000$. Cell dimensions $a=11.205(1), b=$ 14.164(6), $c=15.894(3) \AA, \mathrm{V}=2522(1) \AA^{3}$.

Structure analysis and refinement. The structures were solved by direct methods using the program SHELXS-86 ${ }^{7}$ and refined by full matrix least-squares method using the program SHELX-93 ${ }^{8}$ considering anisotropic temperature factors for all atoms except for the hydrogen atoms that had their positional parameters fixed as determined from Fourier difference maps and a refined single isotropic temperature factor common for all hydrogens. Atomic scattering factors from International Tables for $\mathrm{X}$-ray Crystallography ${ }^{9}$. Final $R,\left(R=\Sigma\left(\left|F_{\text {obs }}-F_{\text {calc }}\right|\right) / \Sigma\left|F_{\text {obs }}\right|\right)$, for all observed reflections with $\mathrm{I}>2 \sigma(\mathrm{I})$ and 300 refined parameters (atomic parameters, scale, extinction coeficint) was $5.3 \%$. Final positional and equivalent isotropic temperature factors for all non-hydrogen atoms with estimated standard deviation in parentheses are given in Table 2. All calculated interatomic distances and angles were in agreement with the expected values for the respective bond types. Tables of hydrogen parameters, anisotropic temperature factors and observed and calculated structure factors are available from one of the authors (YPM). Similar conformation of the rings A, B, C, D, E and F were found for compounds $\mathbf{1}$ and $\mathbf{2}$ in the crystal and are exactly the same as for the structure found for abruslactone $A^{3}$ with the only difference residing, as expected, in the relative posi- tion of $\mathrm{O}(1)$ of compound $\mathbf{1}$, the epimer of 2 . In both crystal structures an intermolecular hydrogen bond is established in a head and tail fashion between $\mathrm{O}(1)$ and $\mathrm{O}(3)$ of molecules related, for epi-abruslactone by the symmetry operations (x, y, z) and (0.5+x, 0.5-y, -z) with $\mathrm{O}(1)-\mathrm{O}(3), \mathrm{O} 1-\mathrm{H} 1$, and O3-H1 distances of 2.919(8), 1.157(8) and 1.902(8) §

Table 2. Atomic coordinates (x $\left.10^{4}\right)$ and equivalent isotropic displacement parameters $\left(\AA^{2} \times 10^{3}\right)$ for Epiabruslactone. $U(e q)$ is defined as one third of the trace of the orthogonalized Uij tensor.

\begin{tabular}{|c|c|c|c|c|}
\hline & $\mathrm{x}$ & $\mathrm{y}$ & $\mathrm{z}$ & $\mathrm{U}(\mathrm{eq})$ \\
\hline $\mathrm{O}(01)$ & $-1216(4)$ & $10753(4)$ & $6927(3)$ & $83(2)$ \\
\hline $\mathrm{O}(02)$ & $-1507(4)$ & $7827(4)$ & $467(3)$ & $66(1)$ \\
\hline $\mathrm{O}(03)$ & $-2824(5)$ & $8961(5)$ & 234(4) & $91(2)$ \\
\hline $\mathrm{C}(01)$ & $-81(6)$ & $10313(6)$ & $7135(4)$ & $65(2)$ \\
\hline $\mathrm{C}(02)$ & $-94(6)$ & $9235(5)$ & $7003(4)$ & $51(2)$ \\
\hline $\mathrm{C}(03)$ & $-64(6)$ & $9044(4)$ & $6027(4)$ & $46(2)$ \\
\hline $\mathrm{C}(04)$ & $916(5)$ & $9533(4)$ & $5507(4)$ & $39(2)$ \\
\hline $\mathrm{C}(05)$ & $859(5)$ & $10609(4)$ & $5716(4)$ & $45(2)$ \\
\hline $\mathrm{C}(06)$ & $899(6)$ & $10823(5)$ & $6658(4)$ & $53(2)$ \\
\hline $\mathrm{C}(07)$ & $-90(6)$ & $7992(5)$ & $5807(4)$ & $56(2)$ \\
\hline $\mathrm{C}(08)$ & $-501(6)$ & $7882(5)$ & 4882(4) & $55(2)$ \\
\hline $\mathrm{C}(09)$ & $297(6)$ & $8399(4)$ & $4250(4)$ & $42(2)$ \\
\hline$C(10)$ & $1482(6)$ & $7847(5)$ & $4138(5)$ & $57(2)$ \\
\hline $\mathrm{C}(11)$ & $-358(5)$ & $8454(4)$ & $3369(4)$ & $38(2)$ \\
\hline$C(12)$ & $-1569(5)$ & $8945(6)$ & $3439(4)$ & $58(2)$ \\
\hline $\mathrm{C}(13)$ & $388(5)$ & $9023(4)$ & 2753(4) & $35(2)$ \\
\hline$C(14)$ & $1123(6)$ & $9684(4)$ & $3036(4)$ & $44(2)$ \\
\hline$C(15)$ & $1362(6)$ & $9921(4)$ & $3949(4)$ & $46(2)$ \\
\hline$C(16)$ & $543(5)$ & $9418(4)$ & $4561(4)$ & $35(2)$ \\
\hline$C(17)$ & $-606(7)$ & $7456(5)$ & $3030(4)$ & $62(2)$ \\
\hline $\mathrm{C}(18)$ & $-897(7)$ & $7441(5)$ & 2094(4) & $63(2)$ \\
\hline$C(19)$ & $92(6)$ & $7846(4)$ & $1561(4)$ & $46(2)$ \\
\hline$C(20)$ & $1264(7)$ & $7284(5)$ & $1668(5)$ & $76(3)$ \\
\hline $\mathrm{C}(21)$ & $309(5)$ & $8876(4)$ & $1808(4)$ & $40(2)$ \\
\hline $\mathrm{C}(22)$ & $-556(6)$ & $9559(4)$ & $1375(4)$ & $49(2)$ \\
\hline $\mathrm{C}(23)$ & $-719(6)$ & $9343(5)$ & $414(4)$ & $52(2)$ \\
\hline $\mathrm{C}(24)$ & $221(7)$ & $8631(5)$ & $122(4)$ & $54(2)$ \\
\hline$C(25)$ & $-220(6)$ & $7792(5)$ & $605(5)$ & $54(2)$ \\
\hline$C(26)$ & $-1804(7)$ & $8741(6)$ & $343(5)$ & $63(2)$ \\
\hline $\mathrm{C}(27)$ & $-810(8)$ & $10234(5)$ & $-104(5)$ & $78(3)$ \\
\hline $\mathrm{C}(28)$ & $2195(6)$ & $9212(5)$ & $5696(4)$ & $51(2)$ \\
\hline$C(29)$ & $936(7)$ & $8806(6)$ & $7491(5)$ & $75(2)$ \\
\hline $\mathrm{C}(30)$ & $-1260(7)$ & $8856(7)$ & $7374(4)$ & $72(2)$ \\
\hline
\end{tabular}




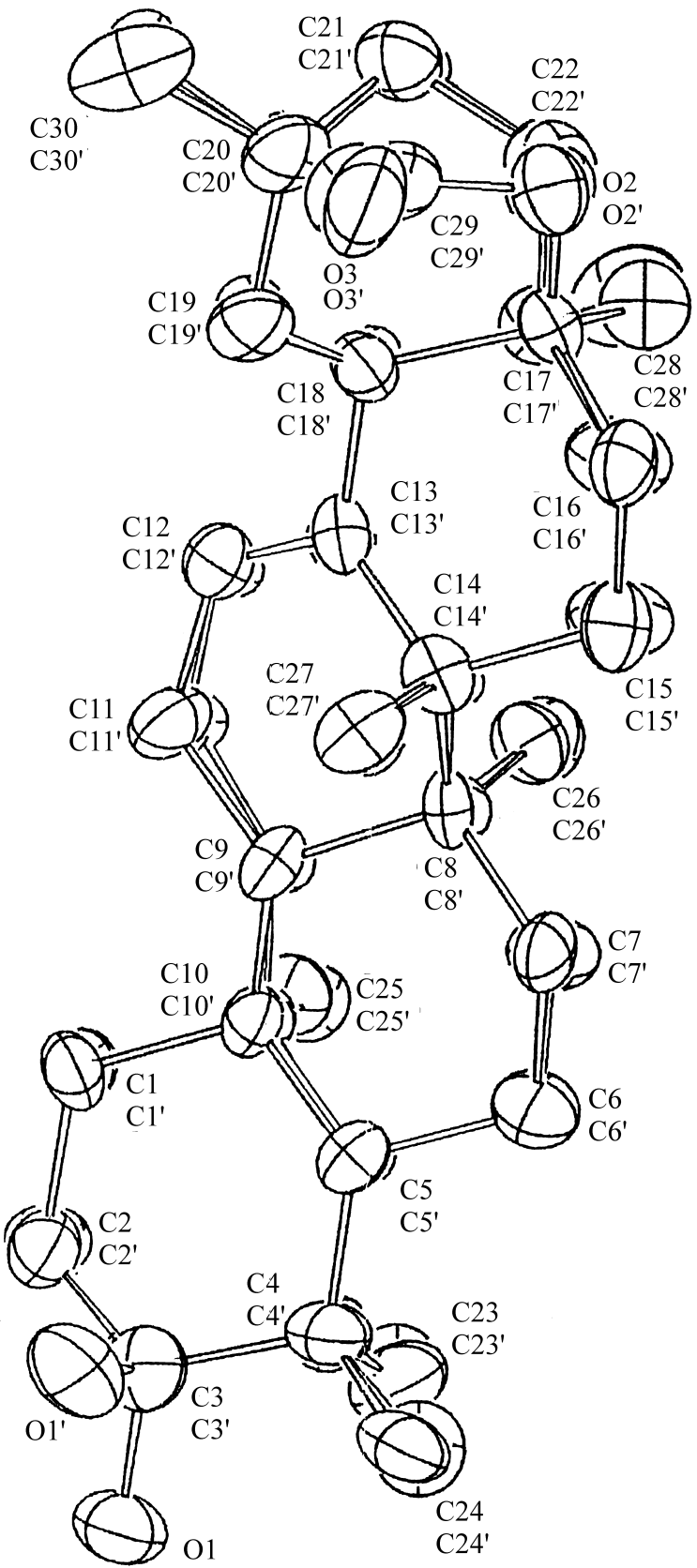

Figure 2. ORTEP representation of the superposition of the relative molecular structures of compounds 1 and 2 (primed = epiabruslactone) showing the different orientation of the hydroxyl group at C-3.

$\mathrm{O}(1)-\mathrm{H}(1)-\mathrm{O}(3)$ angle of $144.1(6)^{\circ}$. Figure 2 is an ORTEP $^{14}$ representation of the superposition of the relative molecular structures of compounds $\mathbf{1}$ and $\mathbf{2}$ including only the non-hydrogen atoms.

\section{Conclusion}

All the experimental findings in this work are conclusive of the existence of the two proposed configurations of the herein studied compound in the plant, compound $\mathbf{1}$ is $3 \alpha$-hydroxyolean-12-en-29,22 $\alpha$-olide and compound $\mathbf{2}$ is
$3 \beta$-hydroxyolean-12-en-29,22 $\alpha$-olide. The isolation of the epimeric pair gives rise to doubts on abruslactone precur-

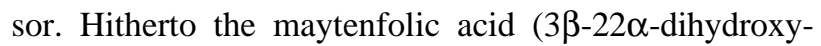
olean-12-en-29 $\alpha$-oic acid) has been considered as abruslactone A precursor. But what could be the 3-epiabruslactone A precursor? In the course of our future chemical investigations we will we will attempt to resolve this question. It would be very interesting to further investigate if the epimers present different biological activities.

\section{Acknowledgments}

The authors are grateful to Prof. Maria das Graças Lins Brandão from the Faculdade de Farmácia, UFMG for the determination of the optical rotation at the Institute of Pharmaceutical Biological, Karlstrasse, Germany, to Professor José Auri Pinheiro from the Universidade Federal do Ceará for the NMR and Mass spectra, to Prof. José Luis Pedersoli from ICB, UFMG for the identification and collection of the botanical material and to CNPq, CAPES, FINEP, FAPEMIG and FAPESP for financial support.

\section{Refrences}

1. Marine-Bettolo, G.B. Il Farmaco, Ed. Sci. 1974, 29, 551.

2. Sousa, J.R.; Jannotti, N.K.; Silva, G.D.F.; Pinheiro, J.A. Gazz. Chim. Ital. 1988, 118, 821.

3. Sousa, J.R.; Silva, G.D.F.; Pedersoli, J.L.; Alves, R.J. Phytochemistry 1990, 29, 3259.

4. Sousa, J.R.; Silva, G.D.F.; Pedersoli, J.L. Química Nova 1990, 13, 252.

5. Corrêa, M.P. Dicionário das Plantas Úteis do Brasil; V. 152, Ministério da Agricultura, Rio de Janeiro, 1969.

6. SDP - Enraf -Nonius Structure Determination Package. Enraf Nonius, Delft, The Netherlands, 1985.

7. Sheldrick, G.M. SHELX86. Program for Crystal Structure Determination. Univ. of Gotingen, Germany.

8. Sheldrick, G.M. SHELX93. Program for Crystal Structure Determination. Univ. of Cambridge, England.

9. International Tables of X-ray Crystallography. Vol. IV, Birmingham: Kynoch Press. (Present Distributor Kluwer Academic Publishers, Dordrecht), 1974.

10. Budzikiewicz, H.; Wilson, J.M.; Djerassi, C. J. Am. Chem. Soc. 1963, 85, 3688.

11. Chang, H.M.; Chiang, T-C.; Mak, C.W. J. Chem. Soc. Chem. Commun. 1982, 1197.

12. Nozaki, H.; Suzuki, H.; Lee, K-H.; McPhail, A.T. J. Chem. Soc. Chem. Commun. 1982, 1048.

13. Firouzabadi, H.; Ghaderi, E. Tetrahedron Lett. 1978, 839.

14. Johnson, C.K. ORTEP Report ORNL-3794, Oak Ridge National Laboratory, Tennessee, 1965. 